\title{
Compositionality as Creative Identity Building ${ }_{1}$
}

\section{Composicionalidade como Construção da Identidade Criativa}

\author{
Liduíno Pitombeira \\ Universidade Federal do Rio de Janeiro
}

\begin{abstract}
In this paper, we examine the concept of Compositionality, proposed by Brazilian composer and scholar Paulo Costa Lima, from the interpenetration of five vectors: inseparability, creation of worlds, criticality, reciprocity and compositional processes. Three of these vectors will be compared with the Theory of Compositional Systems in an attempt to demonstrate that the inseparable flow between theory and practice is essential for the developing of a compositional process that comes with the creation of worlds. The systemic modeling of excerpts of Ponteio Op. 35, by Paulo Costa Lima, will be used as a case study for the compositional planning of a small fragment for flute, clarinet, and bassoon.
\end{abstract}

Keywords: Composicionality; Compositional Systems; Composicional Planning; Musical Composition.

Resumo: Neste artigo, examinamos o conceito de composicionalidade, proposto pelo compositor e intelectual brasileiro Paulo Costa Lima, a partir da interpenetração de cinco vetores: indissociabilidade, criação de mundos, criticidade, reciprocidade e processos do compor. Três desses vetores serão comparados com a Teoria dos Sistemas Composicionais, na tentativa de demonstrar que o fluxo inseparável entre teoria e prática é essencial para o desenvolvimento de um processo composicional que surge com a criação de mundos. A modelagem sistêmica de trechos de Ponteio Op. 35, de Paulo Costa Lima, será utilizada como estudo de caso para o planejamento composicional de um pequeno fragmento de flauta, clarinete e fagote.

Palavras-chave: Composicionalidade; Sistemas Composicionais; Planejamento composicional; Composição musical.

\footnotetext{
1 This work is the result of an oral communication on the round-table "Paulo Costa Lima: identity construction, rhythmic variety and cultural anthropophagy", presented on March 18, 2016, on the occasion of the 3rd Festival de Música Contemporânea Brasileira (Brazilian Contemporary Music Festival), at UNICAMP.
} 
Compositionality is a keyword in the recent writings of Paulo Costa Lima, who proposes this concept from the interpenetration of five vectors, from five perspectives: inseparability, creation of worlds, criticality, reciprocity, and processes of composing. The establishment of compositionality in music has been an addition to other concepts of the compositional field proposed by the first Post-Widmer generation. For some of these composers, Paulo Costa Lima (2012, p.37) associates specific concepts: Jamary Oliveira brings the concept of problem, Fernando Cerqueira, the concept of system, and Lindembergue Cardoso, the practical attitude called "dig in".

The concept of compositionality inhabits other fields of knowledge, such as mathematics, computer science, and the philosophy of language. In the latter, it is known as Frége's (1848-1925) principle, or principle of semantic compositionality, which, according to Pelletier (1994, p. 11), assures us that "the meaning of an expression is a function of, and only of, the meanings of its parts together with the method by which those parts are combined," that is, by the meaning of the individual lexical units and by the syntax that connects those lexical units. The fact that the concept of compositionality in the philosophy of language deals with semantic attributes between structures approximates, to a certain extent, this concept of Paulo Costa Lima's proposal, which suggests to think "in theory and practice as situated in a semantic network with multiple 'others'"' (Costa Lima 2012, p. 17).

In this paper, we will compare three vectors of Paulo Costa Lima's compositionality (the indissociability, the creation of worlds and the processes of composing) with the theoretical references that support our research project, currently developed in the Graduate Program in Music at the School of Music of the Federal University of Rio de Janeiro. ${ }^{2}$ This project proposes experiments on compositional systems, including a compositional methodology, called Systemic Modeling, which we have developed through the convergence of the Theory of Intertextuality and the Theory of Compositional Systems. The latter is particularly interesting for the connection it presents with Paulo Costa Lima, through Herbert Brün (his doctoral advisor) and Fernando Cerqueira. The notion of compositional system for Brün is related in a simple way to a set of instructions declared by a composer in order to control a certain sound producing

\footnotetext{
$2<$ https://ppgm.musica.ufrj.br/desenvolvimento-de-sistemas-composicionais/>
} 
MUSICA THEORICA Revista da Associação Brasileira de Teoria e Análise Musical 2019,

v. 4, n. 2, p. 113-133 - Journal of the Brazilian Society for Music

environment. In a 1979 interview, Brün clearly describes the notion of compositional system:

I could say a system is defined if I say its elements are the 88 keys of a piano; every one of these elements can be in one of two states, either on or off, and I will now write a set of instructions telling those elements when to change their state, how many of them are to change their state at what time, in which sequence, and so on. At that moment I am writing a piano composition, I think (Smith; Smith 1979, p. 68).

On the other hand, Fernando Cerqueira, according to Paulo Costa Lima, treats the notion of system "almost like a worldview of the universe of creation" (Costa Lima, 2012, p. 39). For Cerqueira, "the first reason for any system is to organize the elements by subordinating them to principles or operational mechanisms that make them work as "natural 'parts of a whole' (Cerqueira, 2007, p. 149)." The first part of the definition of Cerqueira is very close to Brün's definition, that is, both definitions deal with principles or operational mechanisms. This operational perspective can also be traced to the foundations of systemic thinking, notably Bertalanffy's General Systems Theory (2008), which cites symbolic systems (music, language, visual arts, etc.) as a field that is constituted by "rules of the game". In addition, the definition of Cerqueira has even more similarity with the definition of Bertalanffy when it mentions the terms "parts" and "whole", considering that Bertanlanffy defines a system as "a complex of elements in interaction" (2008, p. 84). There is also the cosmological impulse (observed in Cerqueira as well) that supports the General Systems Theory in its early stages: Bertalanffy cites a hierarchy of systems, according to Boulding (1956), in which one can observe a more comprehensive agenda (see Table 1).

At this point, I should mention "the inseparability between theory and practice in composing," as a vector that is complexly imbricated with the creation of worlds. For this, I propose that a musical work can arise from a continuous flow between theory and practice, the latter being the performance action on a theory. Such an action, that is, such a practice is immediately transmuted into theory that needs to be performed. The cycle continues, starting from the most abstract to the most concrete. And it all begins with the creation of a world, of a universe, charged at first with its own intrinsic laws of functioning. Such a universe may have isomorphic characteristics with our own everyday universe 
or be totally distinct and even absurd. The former is transfigured into art through an articulation with cognitive processes, such as the ones described in Larson (2012). The latter needs to be artificially designed in terms of processes of cohesion and coherence, so as to make sense to humans. In any case, what matters to a composer is a universe as an abstract construct, even if inheriting ordinary laws and principles.

\begin{tabular}{|c|c|c|}
\hline Level & Description and Examples & Theory and Models \\
\hline Static Structures & Atoms, molecules & Structural formulas of chemistry \\
\hline Clock Works & Clocks, solar systems & Newtonian and Einsteinian mechanics \\
\hline Control & Thermostat & Cybernetics \\
\hline \multicolumn{3}{|l|}{ Mechanisms } \\
\hline Open Systems & Cells & Metabolism, genetic code \\
\hline Lower & Plant-like organisms & Lacking theory and models \\
\hline \multicolumn{3}{|l|}{ Organisms } \\
\hline Animals & Nervous systems, learning & Automata Theory, feedback \\
\hline Man & Symbolism, self-awareness & Incipient Theory of symbolism \\
\hline $\begin{array}{l}\text { Socio-cultural } \\
\text { Systems }\end{array}$ & $\begin{array}{l}\text { Populations of organisms, symbol- } \\
\text { determined communities }\end{array}$ & $\begin{array}{l}\text { Statistical laws in population dynamics, } \\
\text { sociology, economics, history. }\end{array}$ \\
\hline $\begin{array}{l}\text { Symbolic } \\
\text { Systems }\end{array}$ & $\begin{array}{l}\text { Language, logic, mathematics, arts, } \\
\text { moral }\end{array}$ & $\begin{array}{l}\text { Algorithms of symbols: "rules of the } \\
\text { game", such as in visual arts, music, etc. }\end{array}$ \\
\hline
\end{tabular}

Table 1: Hierarchy of Systems, according to Bertalanffy $(2008$, p. 53)

It is from universes (natural or artificial) that a composer proposes systems. A system thus emerges from the performance of a world, from the selection of relationships in a vast sea of epistemological possibilities. Naturally, the proposition of a system needs not to be conscious, stated in detail as a set of intentions. In fact, in most cases it seems to integrate subliminally the processes of composing (and here I bring another vector of Paulo Costa Lima's compositionality). To make it clear, we propose a small exercise: let us say that, among the infinite possible universes, we decide to use as our starting point a universe that is totally isomorphic with our natural world. Creating a system means performing this world by selecting relationships between objects that do not yet exist in a particular state but only generically. We can informally enumerate a series of observations intrinsic to our everyday universe, which may have particular metaphorical interest in the creation of musical art works. For example:

1. Explosions produce noises in the environment and are followed by sound residues. The musical counterpart for these phenomena may consist of resonances and scattered fragments after an abrupt musical event, such as an orchestral tutti in fortissimo, for example; 
2. Energies are preserved and converted: potential energy becomes kinetic energy and vice-versa. Power is function of force and velocity $(P=f . v)$. Musically, dynamics and durations compensate each other in such a way that a musical event brings performance difficulties when it is very fast and very intense at the same time.

3. Ambiguities and uncertainties are present in our everyday life (Brownian motion, non-linear dynamic systems, chaotic systems, etc.). Ambiguity can be also present in the musical universe in terms of deceptive cadences, abrupt paratactical parenthesis, ${ }^{3}$ mobile form, determination of root for incomplete triads, etc.

4. Dualities (hot versus cold, night versus day, etc.) of our universe are also present in the musical domain: theme A versus theme B, Tonic versus Dominant, etc.

5. Mutations: beings become deformed, mutated; external agents and parasites cause diseases, etc. The process of mutation manifests itself in the musical domain through gesture deformations, filtering, conversion, ${ }^{4}$ transformations, etc.

6. External and transient interferences, such as virus contaminations, may become prominent in later stages of specific processes. A remarkable application of this process in the music realm is the concept of promissory note, by Edward Cone (1982).

7. The life cycle (birth, growth, decline, and death) can be associated with musical climax and nadir, expressed through melodic high and low points and contours.

8. Physical models, such as the behavior of fluids under specific pressure and temperature may be applied to musical phenomena as shown by Xenakis (1990).

\footnotetext{
${ }^{3}$ For a detailed discussion of parataxis in music see Souza (2007).

${ }^{4}$ Inspired by the filters employed in electroacoustic music, the filtering procedure consists of removing unwanted components of a sonority. For example, if a musical fragment is filtered through the pentatonic scale CDEGA, only these pitch classes are allowed to appear in the new fragment. On the other hand, conversion is a type of filtering that adjusts the new material from the filtering constraints. Thus, the procedure of conversion through the same pentatonic filter just mentioned would convert the entire passage into pentatonic.
} 
9. Natural forces or principles, such as gravity, can be expressed in music through tonicization (tonal gravity) or "the tendency of a note heard as above a reference platform to descend" (Larson 2012, p. 22). Larson mentions two other concepts that can be applied to a cognitive melodic understanding: inertia and magnetism.

10. Linguistic systems, culturally or artificially shaped, can be an important theoretical reference to the discussion of musical syntax. The idea of producing infinite structures from finite elements inspire the infinite parametric combinations starting from finite musical sets.

11. Simplicity, as expressed by the Ockam's razor, i.e., the principle of the least effort, can be found in parsimonious motion among voices in a harmonic structure.

12. Complexity of real systems with their several interconnected and inter-related layers have their musical counterpart in musically complex structures, such as the ones present in the works of the New Complexity school (Ferneyhough, Finnissy, Birthwistle, etc.).

13. Auto-similarity, as shown in fractal geometry, can be found in musical structures (such as the trichordal subsets of 0167, for example), as well as be used in compositional planning (such as the rhythmic/formal planning used in Cage's First Construction in Metal or in Babbitt's Composition for four instruments). ${ }^{5}$

Table 2 summarize the abovementioned observations of our universe with potential for artistic usage. Among the physical manifestations that make up our universe we will focus on two to create our system: economy of movement and conservation of energy. The first relates to the principle of the least effort, enunciated by French philosopher Guillaume Ferrero in 1894, and also with the law of parsimony of William of Ockam, a Franciscan, theologian, and English scholastic philosopher of the thirteenth century. This law of parsimony can be translated musically, for example, in voice-leading movements by the smallest possible route, something constantly experienced in traditional harmony partwriting in four voices, and also in the parsimonious connection between triads,

\footnotetext{
${ }^{5}$ For a detailed explanation of this principle see Pitombeira (2012, p. 268).
} 
MUSICA THEORICA Revista da Associação Brasileira de Teoria e Análise Musical 2019, v. 4, n. 2, p. 113-133 - Journal of the Brazilian Society for Music

by movement of at most a major second, within the perspective of the NeoRiemannian theory (Cohn, 1998).

\begin{tabular}{|c|c|c|}
\hline \multicolumn{2}{|c|}{ Observations of the everyday universe } & \multirow{2}{*}{$\begin{array}{l}\text { Musical Metaphors } \\
\text { Fragments, resonances }\end{array}$} \\
\hline Explosion & Residues and noises & \\
\hline $\begin{array}{l}\text { Energy and power } \\
\text { conservation }\end{array}$ & $\begin{array}{l}\text { Potential energy } \rightarrow \text { Kinetic } \\
\text { energy, }(P=f . v)\end{array}$ & Dynamics $\rightarrow$ rhythmic activity \\
\hline Ambiguities and uncertainties & $\begin{array}{l}\text { Brownian motion, non-linear } \\
\text { dynamic systems, chaos }\end{array}$ & $\begin{array}{l}\text { E-G = C major? E minor? } \\
\text { Deceptive cadences, abrupt } \\
\text { parenthesis, etc. }\end{array}$ \\
\hline Dualities & Hot $x$ cold, Night $x$ Day,,.. & Theme $\mathrm{A} \times$ Theme $\mathrm{B}, \mathrm{I} \times \mathrm{V}, \ldots$ \\
\hline Mutations & Genetic transformations & $\begin{array}{l}\text { Gesture deformations, filtering, } \\
\text { conversion, transformations. }\end{array}$ \\
\hline External interferences & Virus, contaminations & Promissory Notes (Cone, 1982) \\
\hline $\begin{array}{l}\text { Life cycle (birth, growth, } \\
\text { decline and death) }\end{array}$ & Climax, nadir & Melodic high points, contours \\
\hline Physical models & Gas theory & Xenakis (1990) \\
\hline Natural forces & Gravity & Tonicization, centricity \\
\hline Linguistic systems & $\begin{array}{l}\text { Finite elements } \rightarrow \text { infinite } \\
\text { structures }\end{array}$ & $\begin{array}{l}\text { Infinite possibilities of parametric } \\
\text { combinations starting from finite } \\
\text { sets }\end{array}$ \\
\hline Simplicity & $\begin{array}{l}\text { Ockam's razor, principle of the } \\
\text { least effort }\end{array}$ & Economy of motion \\
\hline Complexity & $\begin{array}{l}\text { Multi-layered inter- } \\
\text { relationships }\end{array}$ & New Complexity (Ferneyhough) \\
\hline Auto-similarity & Fractal geometry & $\begin{array}{l}\text { Music structures based on the auto- } \\
\text { similarity principle }\end{array}$ \\
\hline
\end{tabular}

Table 2: Observations about our everyday universe and its musical metaphors

The second physical manifestation considers the close relationship between force and velocity, in the scope of power conservation (energy spent in a given time interval). According to the expression $P=F . v$, in order to maintain the same power value, speed must be reduced as force value increases. In practice, we know that it is impossible for a car to start moving in fifth gear (suitable for high speeds) and, likewise, it is impossible for it to reach a high velocity in the first gear (suitable for a high force, capable of breaking the inertia). ${ }^{6}$ This principle can translate musically into the balance and transfer of energy between dynamics and rhythmic figurations. In other words, the mechanical power capacity of a musician can be used in strong dynamics or in rapid rhythmic figurations, but not in both simultaneously. As an example of the first case (parsimonious movement), we have a passage from Brahms' Concerto for Violin, Cello and Orchestra, Op. 102. In this passage, shown in Example 1, the triads

${ }^{6}$ In vehicles with manual gearbox. 
connect themselves through parsimonious movement, in which only one note of the triad moves semitone above or below (Table 3).
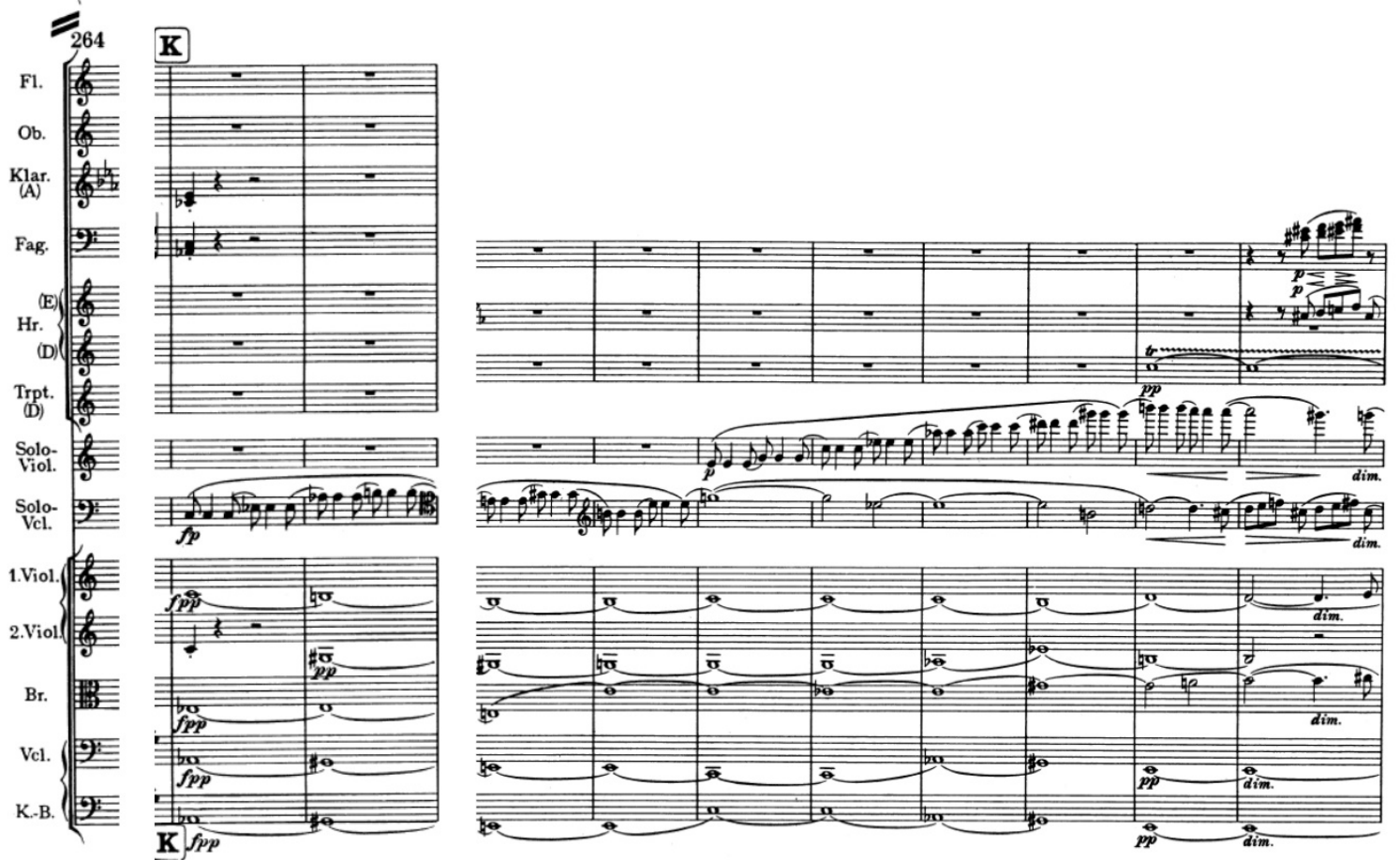

Example 1: Excerpt from Brahms' Concerto for violin, cello and orchestra, Op. 102.

\begin{tabular}{|l|l|l|l|l|l|l|l|l|l|l|l|l|}
\hline $\mathrm{C}$ & $\mathbf{- 1}$ & $\mathrm{B}$ & 0 & $\mathrm{~B}$ & 0 & $\mathrm{~B}$ & $\mathbf{+ 1}$ & $\mathrm{C}$ & 0 & $\mathrm{C}$ & 0 & $\mathrm{C}$ \\
\hline $\mathrm{E} b$ & 0 & $\mathrm{D} \#$ & $\mathbf{+ 1}$ & $\mathrm{E}$ & 0 & $\mathrm{E}$ & 0 & $\mathrm{E}$ & $\mathbf{- 1}$ & $\mathrm{E} b$ & 0 & $\mathrm{E} b$ \\
\hline $\mathrm{A} b$ & 0 & $\mathrm{G} \sharp$ & 0 & $\mathrm{G} \#$ & $\mathbf{- 1}$ & $\mathrm{G}$ & 0 & $\mathrm{G}$ & 0 & $\mathrm{G}$ & $\mathbf{+ 1}$ & $\mathrm{A} b$ \\
\hline
\end{tabular}

\begin{tabular}{|l|l|l|l|l|l|l|l|l|l|l|l|l|}
\hline I & & i & & bVI & & bvi & & III & & iii & & I \\
\hline
\end{tabular}

Table 3: - Parsimonious movement between the triads in the seven-measure excerpt, from the letter K, of Brahms' Concerto for violin, cello and orchestra, Op. 102

Another example of parsimonious movement is shown in the initial excerpt of Ponteio Op. 35, by Paulo Costa Lima (Ex. 2). In this section the right and left hands present versions of the tetrachordal class [0257], when observed horizontally. ${ }^{7}$ In addition, the vertical observation of the sonorities reveals two tetrachordal classes, [0156] and [0134] in continuous parsimonious flow.

${ }^{7}$ Horizontal segmentation is justified by Gestalt's Law of proximity. In this work, set classes are represented by the prime forms inside brackets. 

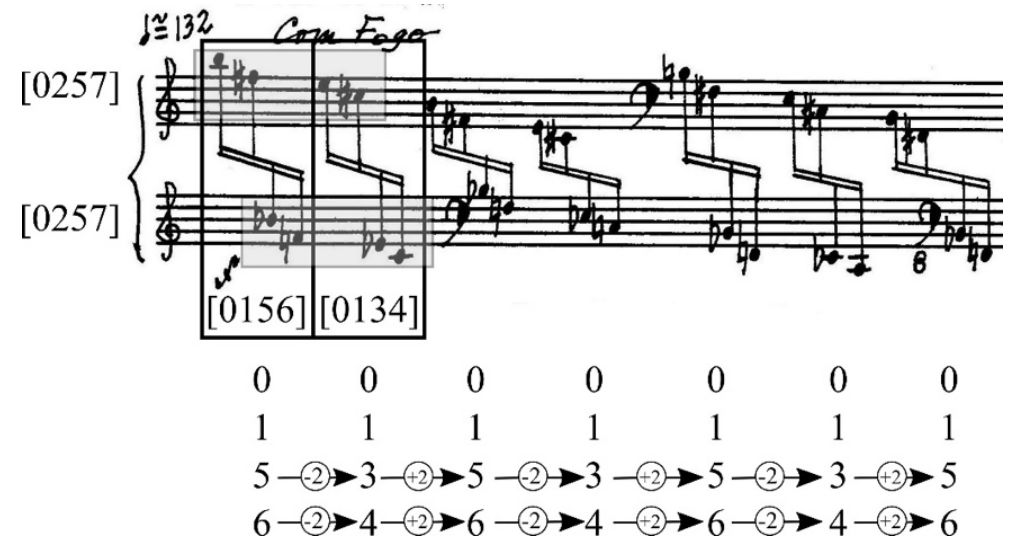

Example 2: Initial gestures of Ponteio Op. 35, by Paulo Costa Lima

As an example of the second case (power conservation), we have the alternation between $m f$ and $p$, followed by the alternation between $f f$ and $p p p$, in the excerpt shown in Example 3, from the piano work Le Merle Bleu, from the first book of the Catalog of Birds, by Messiaen. To faster notes are assigned low dynamics and vice-versa, which is totally coherent with the law of power conservation.

After examining possible musical achievements of energy conservation and parsimony, we can resume the construction exercise of our system, which will consist of only two statements: 1) The dynamics are inversely proportional to the durational values of the rhythmic figures; 2) The vertical pitch-classes are connected parsimoniously. For identification purposes this system will be called Ockam System.

The creation of a compositional system is made possible through a set of statements, diagrams, tables, or a computational algorithm. The act of writing these statements constitutes a performance of the chosen universe, transforming theory and practice, even if momentarily, because, once stated, the system crystallizes into a theory that needs to be performed again, i.e., practiced. The performance of a system is the activity we call compositional planning, in which the treatment expands from relations to objects, from generality to particularization. It is also in the compositional planning that the undeclared parameters in the system are considered by the composer, both in free form as well as submitted to a specific and detailed planning. Then we can make a possible planning for the Ockam System, previously stated. The planned fragment will be an aphoristic miniature, like Webern's short works (we think here in the third movement of Drei Kleine Stück, Op. 11, which has only ten bars). The 
planning initially consists of particularizing the scenario by the inclusion of objects that satisfy the relations described in the system. In a second phase the composer can freely add undeclared parameters. In Figure 1, we have a diagram that consists of set classes parsimoniously connected and a set of dynamics that foreshadow the rhythmic activity of the passage, in such a way that in the blocks associated with strong dynamics we will have long static notes and between these blocks there will be short notes with more rhythmic activity. The crescendo signals indicate, in addition to the increase of dynamics, a decrease of rhythmic intensity, just as the signs of decrescendo indicate the opposite.
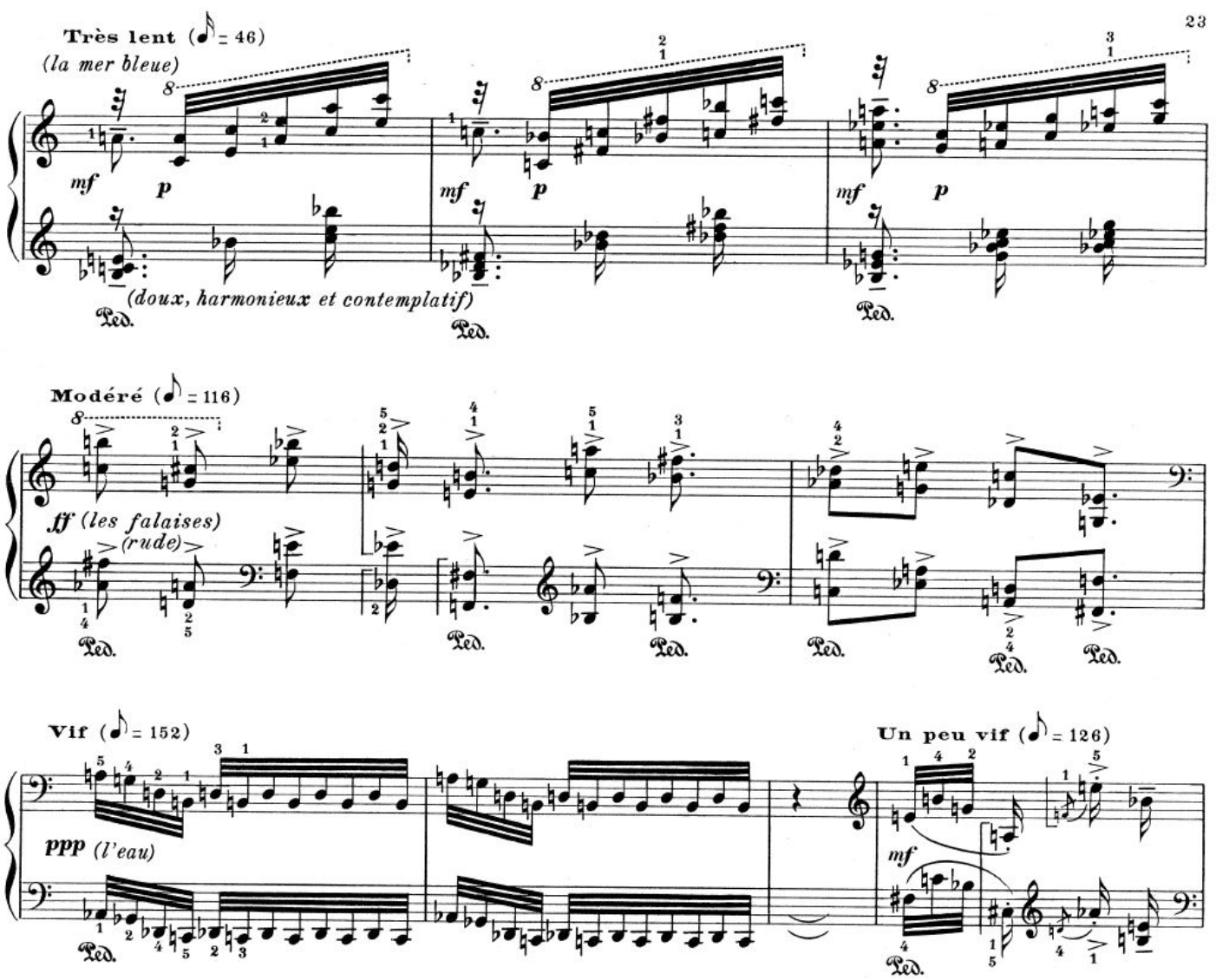

Example 3: Excerpt from Le Merle Bleu, from the first book of the Catalog of Birds, by Messiaen

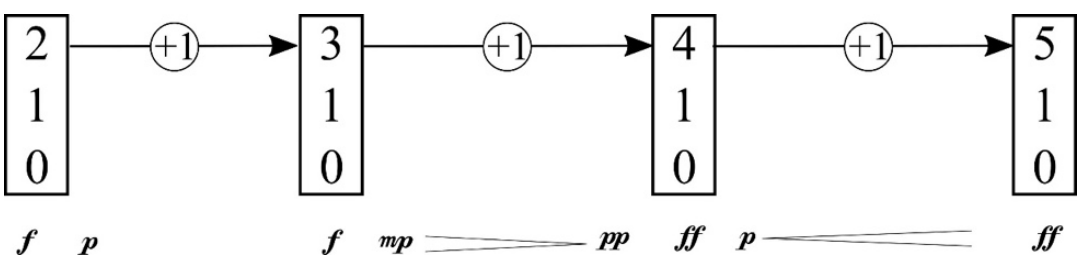

Figure 1: Compositional planning based on the Ockam System 
MUSICA THEORICA Revista da Associação Brasileira de Teoria e Análise Musical 2019, v. 4, n. 2, p. 113-133 - Journal of the Brazilian Society for Music

The plan of Figure 1 came about when we performed the system, transforming the theory stored within the Ockam System into practice. This practical characteristic of the compositional plan soon turns itself into a theory that must again be performed to become practice. A composer performs the plan making it to emerge to the surface, reducing the ambiguity of the instructions of this plan, particularizing the values of the parameters declared in the system. Figure 2 shows a possible plan of pitch-classes for the first and second measures of a piece for three wind instruments. One can see that the set class [012] (as indicated in Figure 1) appears first vertically and then is distributed horizontally in several fashions in the instrument of the upper layer. The last four pitch-classes are duplicated at the end of measure 1. For the second measure, set class [013] also appears vertically at the beginning and then one of its subsets (interval class 1) becomes the basic idea used to build a melodic line for the middle layer instrument. The compositional planning for the other remaining measures is similarly accomplished. The next step consists of including specification for other parameters not stated in the system (rhythm, articulation, timbre), thus producing a new set of instructions: the score (Ex. 4).

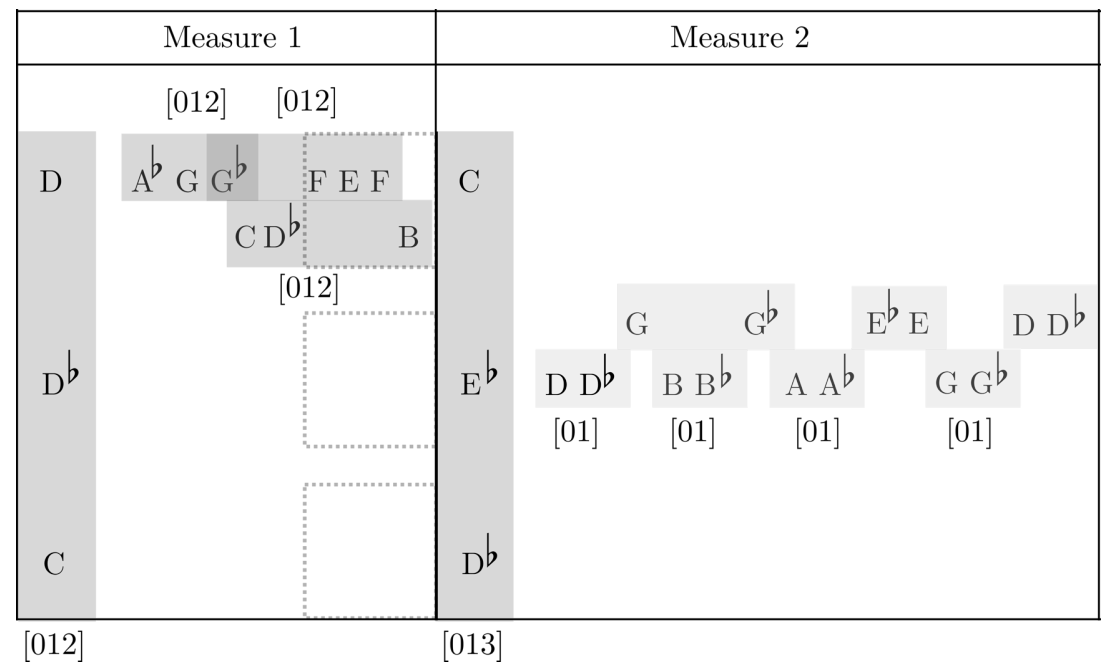

Figure 2: Compositional planning of measures 1 and 2, based on the Ockam System 


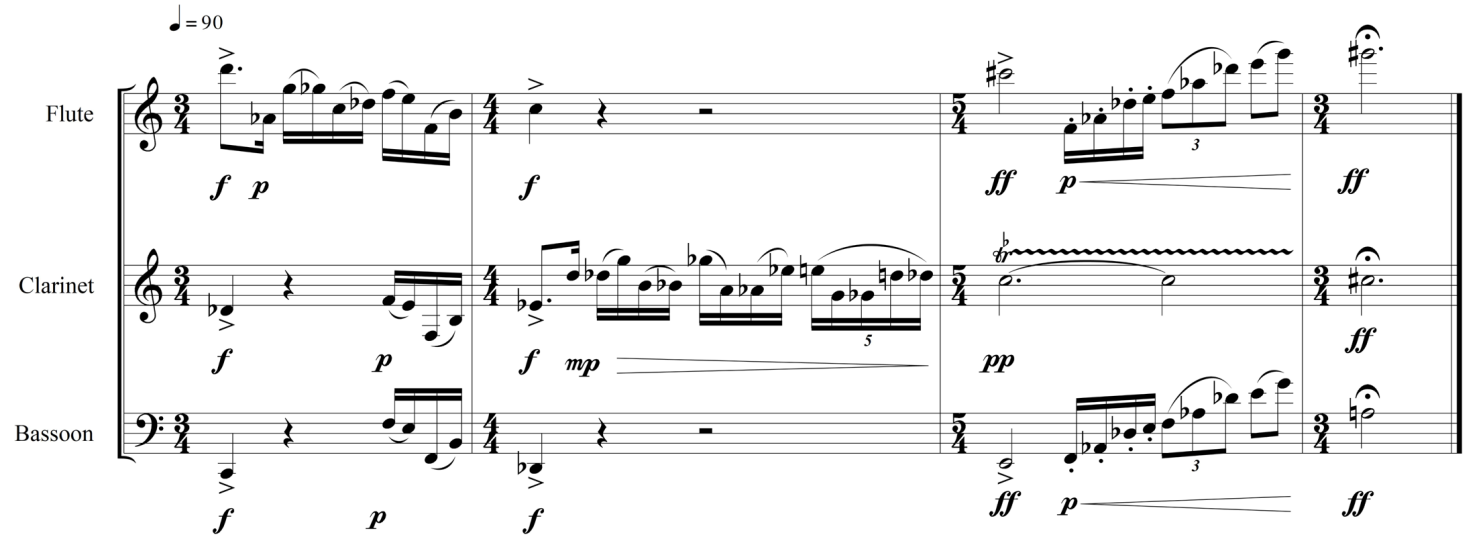

Example 4: Score generated from the compositional planning, which was based on the Ockam System (score in concert pitch)

Continuing the cycle, this score, through multiple interpretive looks, becomes a new theoretical possibility. ${ }^{8}$ The possible performances of these instructions turn theory into practice again. The cycle can continue if we investigate the different impacts that a performance of this score causes on different listeners. The diagram in Figure 3 illustrates our theory-practice cycle proposal that is put into motion when performing a universe, among many other infinite universes, with the intention of creating a musical work.

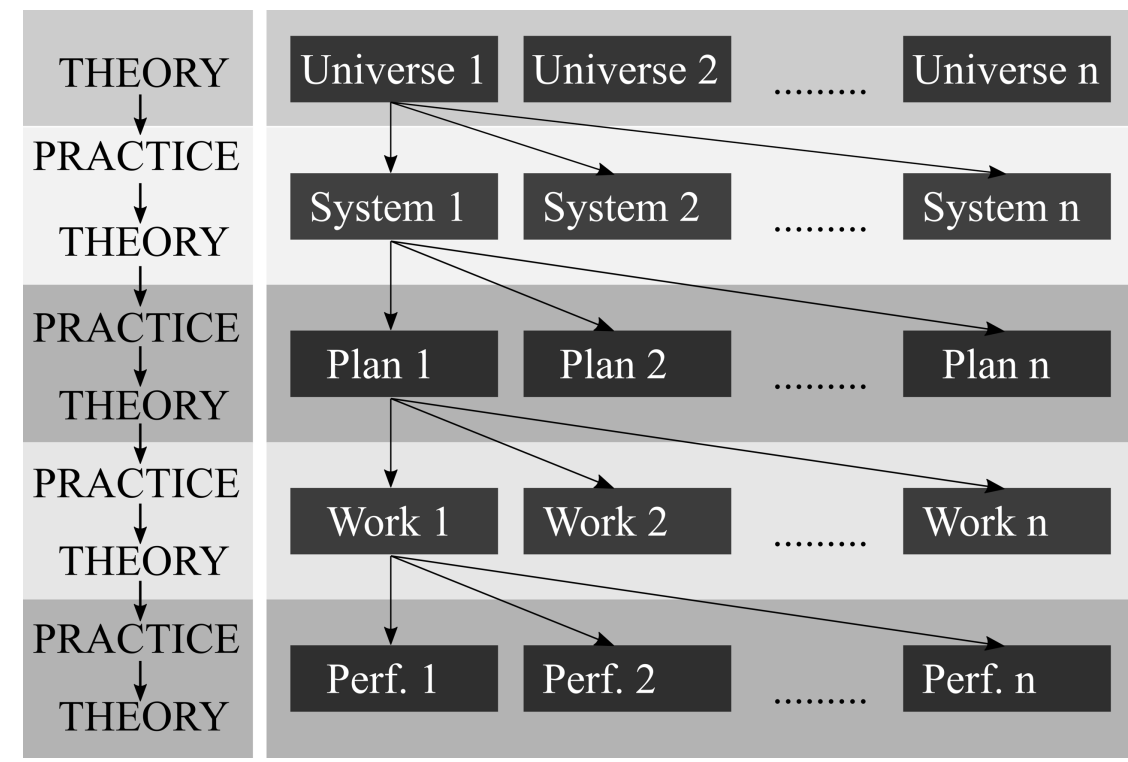

Figure 3: Theory-practice cycle in compositional making

${ }^{8}$ Johnson (1997) deeply discusses the notion that score and performance are radically different. 
The Ockam System, used to compose the fragment shown in Example 4, was created from scratch from a series of definitions isomorphically connected with our everyday universe. This type of compositional system is called 'original' as a contrast with a 'modeled' system, which derives its rules directly from another piece.

Looking back at the beginning of Paulo Costa Lima's Ponteio Op. 35 (shown in Example 2), we have seen that it incorporates deeply the principle of parsimony, since it presents a smooth movement in the set class level. Therefore, a model for this piece could have this principle embedded within it. An examination of the first page of the work (Ex. 5) reveals that the arpeggiated chords are initially constructed by alternating two intervals: perfect fourth (interval class 5) and minor third (interval class 3), which themselves differ by a major second. This alternation follows almost a stabilization in the minor third interval, a timid return of the fourth interval, and the contamination of the "organismo" by two different intervals (tritone, or interval class 6, and major third, or interval class 4 , which are also connected parsimoniously to the original intervals: 3 and 5).

Observing the intervallic profile of the right and left hands of the piano, represented as curves in the diagram of Figure 4, we can clearly see alternation (beige colored bands, labeled with A), stability (green bands labeled with $S$ ) and contamination (blue bands, labeled C). The numbers attached to the letters A, S, $\mathrm{C}$ indicate the amount of occurrence of the intervals. Thus, for example, the right hand of the first line of Example 5, has ten groups of intervals (labeled A10 in the diagram). These intervals alternate among themselves. Therefore, the curve shows the alternation (triangular pattern) and the region is given a beige background. The next group, formed by two intervals, is stable (green background), and so on. This diagram is the basis for a modeled compositional system (or systemic model), which is revealed if we take those profiles and their narratives as syntactic models, without considering the particular values of the intervals, i.e., if we generalize them. Since the entire passage is built with only four intervals $(5,3,6$, and 4$)$, they can be generalized simply by replacing them with letters $(\mathrm{x}, \mathrm{y}, \mathrm{z}$, and $\mathrm{w})$. Table 4 presents this generalization and, therefore, is a systemic model for Paulo Costa Lima's Ponteio Op. 35 in terms of intervallic profile, which has embedded within it the three intervallic behaviors: alternation, 
stability, and contamination. For identification purposes this system will be called Ponteio System.
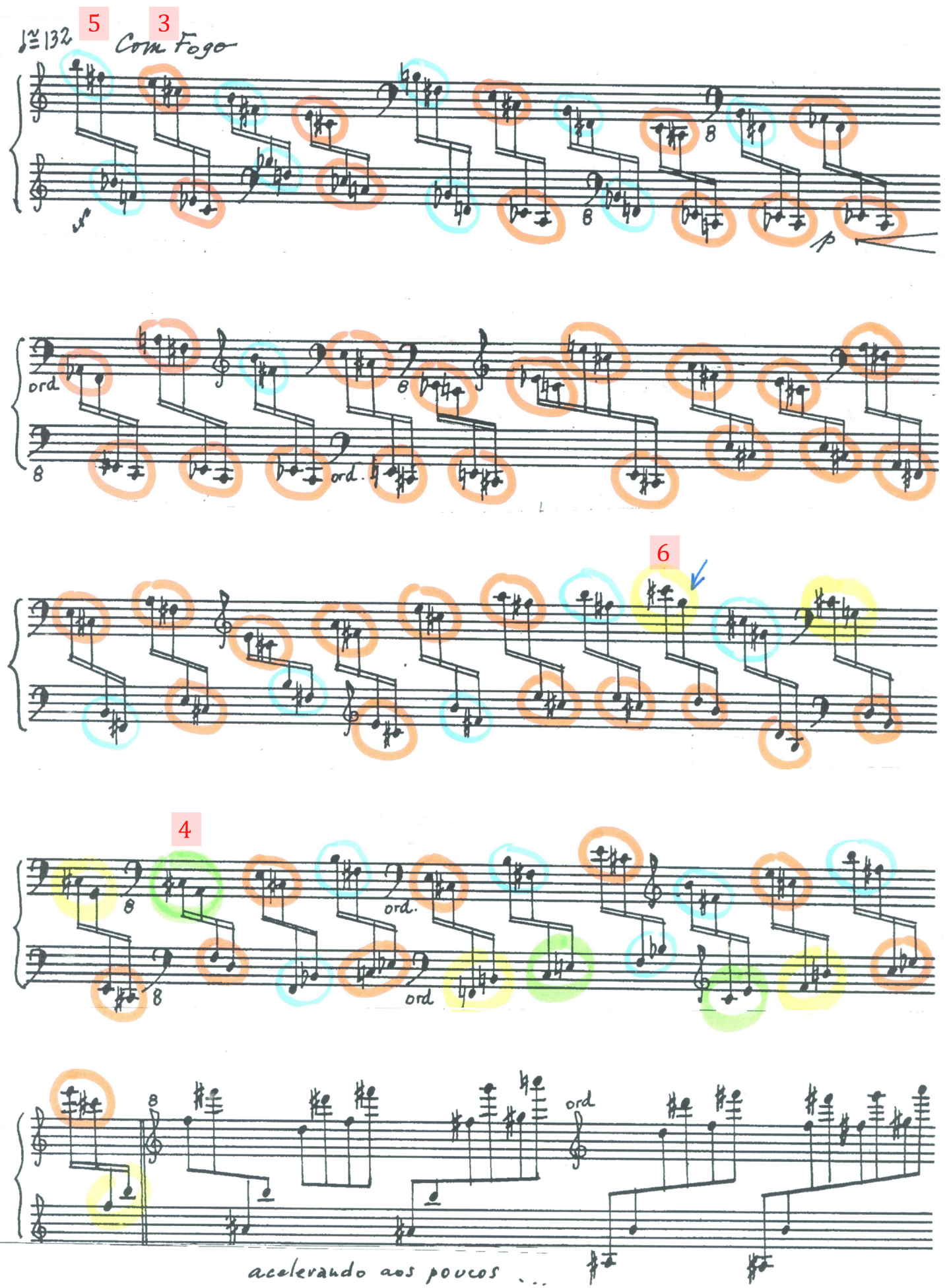

Example 5: First page of Ponteio Op. 35, by Paulo Costa Lima, in which one can see the interval classes 5, 3, 6 and 4, as building blocks of the sonorities 
MUSICA THEORICA Revista da Associação Brasileira de Teoria e Análise Musical 2019, v. 4, n. 2, p. 113-133 - Journal of the Brazilian Society for Music

Theory and Analysis@ TeMA 2019 - ISSN 2525-5541
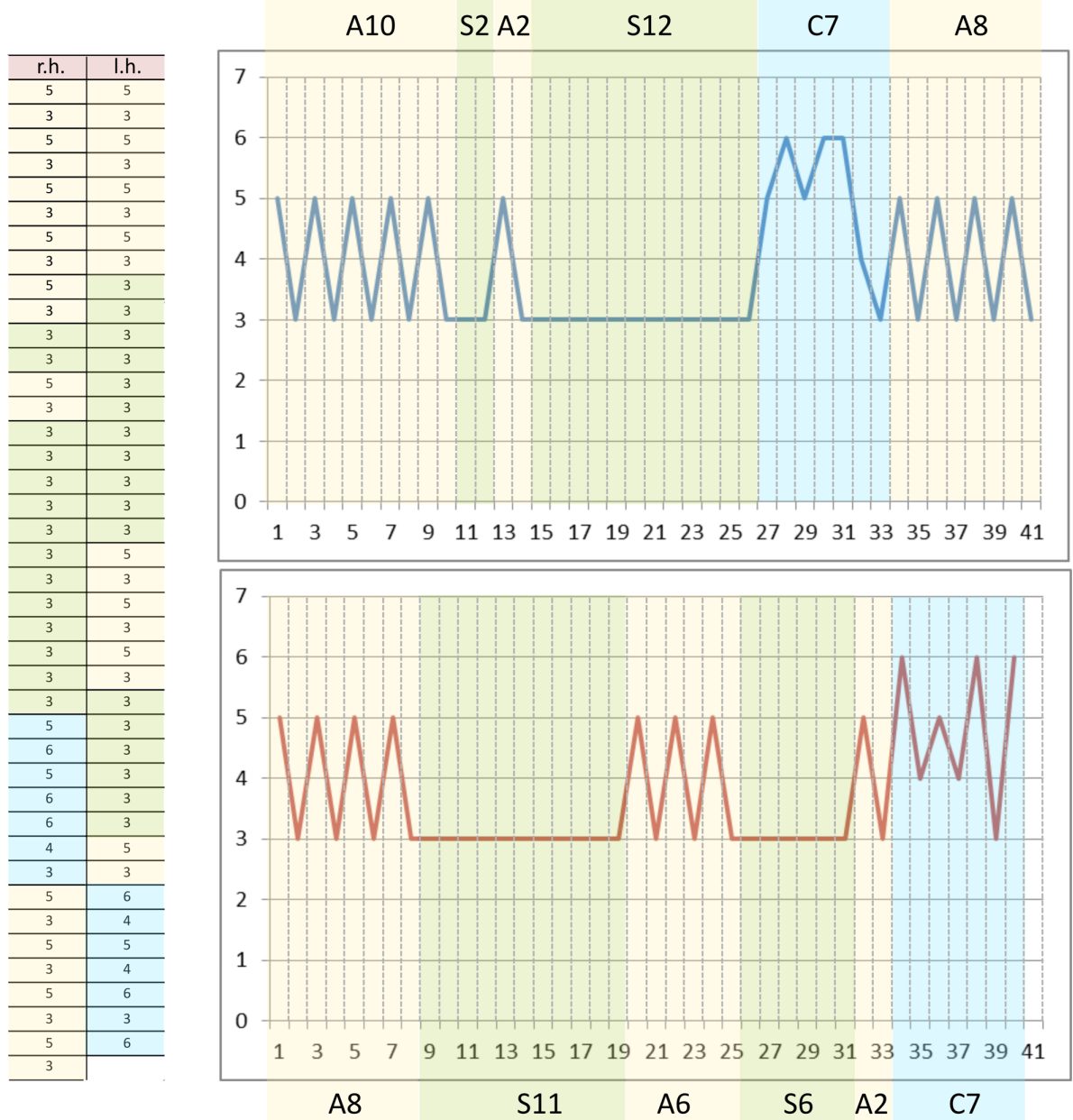

Figure 4: Intervallic profile of the right hand (top graphic) and left hand (bottom graphic) of Ponteio Op. 35, by Paulo Costa Lima. The table on the left of the diagram contains the list of intervals. The diagrams (on the right) are cartesian representation of those intervals (vertical axis) in terms of their ordered occurrence through time (horizontal axis)

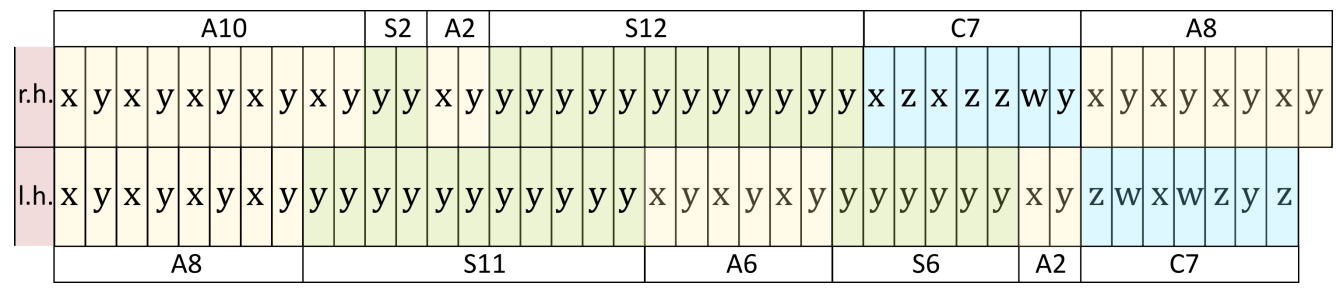

Table 4: The Ponteio System: generalization of the intervallic profile of Ponteio Op. 35, by Paulo Costa Lima. The three colors (beige, green, and blue) are respectively associated with the three intervallic behaviors: alternation, stability, and contamination. The letters $x, y, z$, and $w$ correspond to interval classes 5, 3, 6, and 4 respectively 
The Ponteio System inherits the intrinsic intervallic configurations from the original work. If the compositional planning of a new work starts exclusively from Table 4, without previous knowledge of the rhythmic figurations employed in the original work, we will be free from the influence of these figurations to focus solely on the interval narrative.

The compositional planning of a new fragment starts by choosing four new interval classes. The alternation will take place between major thirds (4 semitones) and minor seconds (1 semitone). In contrast with the original work (Ponteio), there is no parsimonious connection between the two main intervals of the new fragment. The parsimony will be applied here only in the 'contamination' segments, by the use of minor thirds (3 semitones) and major seconds (2 semitones), which can be connected parsimoniously to both main intervals. ${ }^{9}$ Example 6 shows the detailed planning of the intervals based on the Ponteio System, i.e., in the systemic model shown in Table 4.
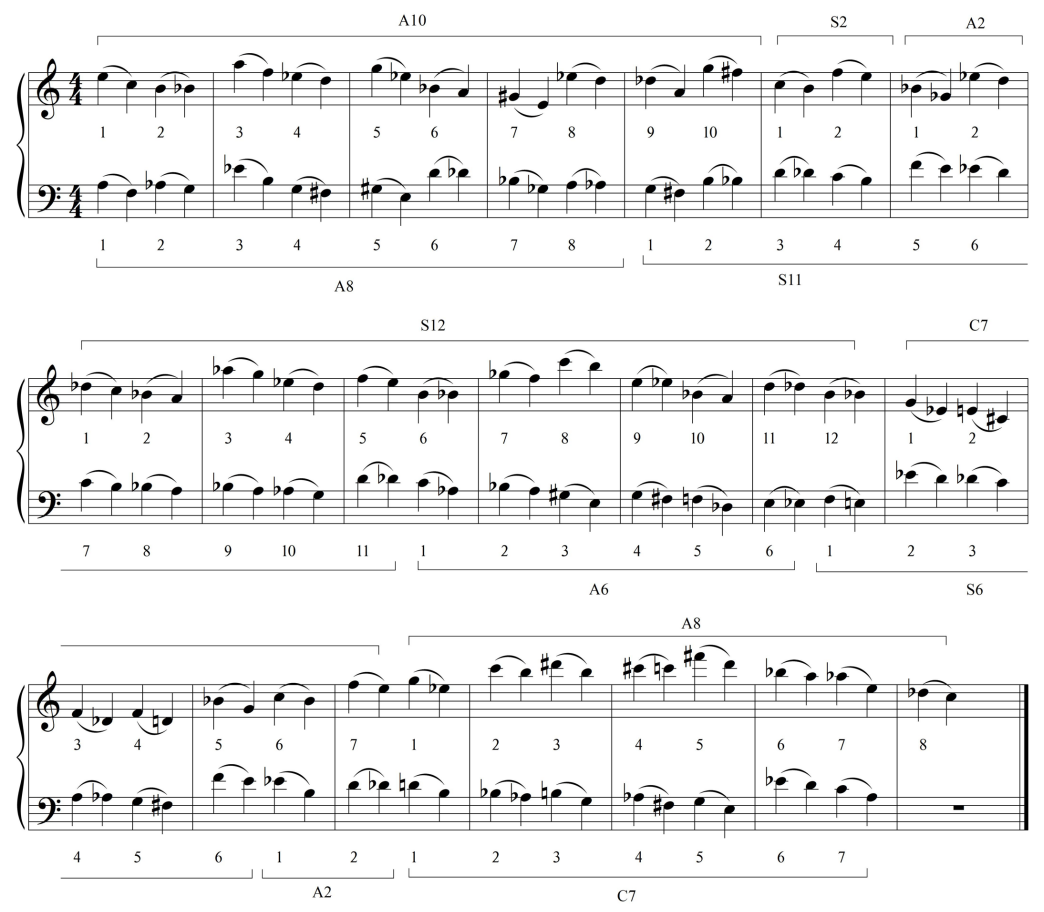

Example 6: Intervallic planning of a new fragment based on the Ponteio System, considering $\mathrm{x}, \mathrm{y}, \mathrm{z}$, and $\mathrm{w}$ (Table 4) equals to $4,1,3$, and 2

\footnotetext{
$9[3]=\underline{1}+2=\underline{4}-1 ;[2]=\underline{1}+1=\underline{4}-2$; (intervals of contamination are written inside brackets; main intervals are written bold and underline).
} 
This compositional planning will be transformed into a passage for wind trio (flute, clarinet, and bassoon). In order to distribute the two-line staff of the compositional planning to the texture of this instrumental formation, we will apply five operations: 1) Resonance, in which a specific pitch has its durational value freely expanded; 2) Octave/Unison Doubling (literal, with omission of notes, or with fragmentation into smaller rhythmic values); 3) Literal repetition; 4) Repetition with irregular Augmentation/Diminution; and 5) Echo, which consists of a shifted repetition of a segment (at unison or octave). Also, it is noteworthy to mention that we are dealing with intervals classes, which means that a minor second and a major seventh will both be valid for interval class 1 , for example.

Example 7 shows how the application of the five aforementioned operations transformed the compositional planning (Ex. 6) into a wind trio fragment. The rhythm was freely chosen. Dynamics and articulations can be freely applied as well. Since this new fragment and the previous one (Ex. 4) are written for the same instrumental formation, we can juxtapose them in order to form a larger passage that can be used as a portion of a piece. This procedure is shown in Example 8 (the second fragment now has dynamics and articulations). 

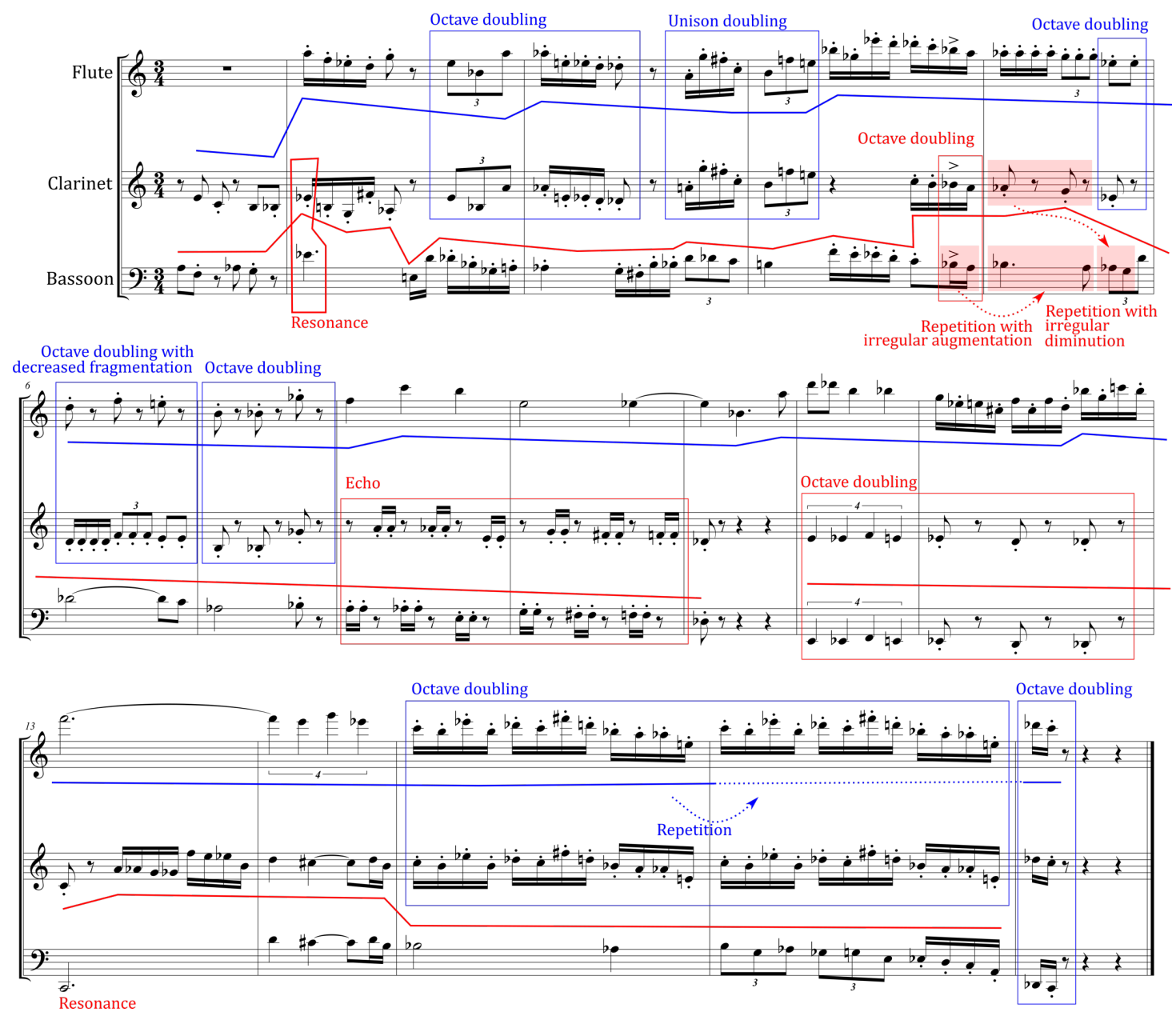

Example 7: A fragment composed by Liduino Pitombeira according to the Ponteio System, i.e., based on the systemic model of Ponteio Op. 35, by Paulo Costa Lima. Blue and red lines correspond to upper and bottom staves of the intervallic planning (Ex. 6).

The score is written in concert pitch 
MUSICA THEORICA Revista da Associação Brasileira de Teoria e Análise Musical 2019, v. 4, n. 2, p. 113-133 - Journal of the Brazilian Society for Music
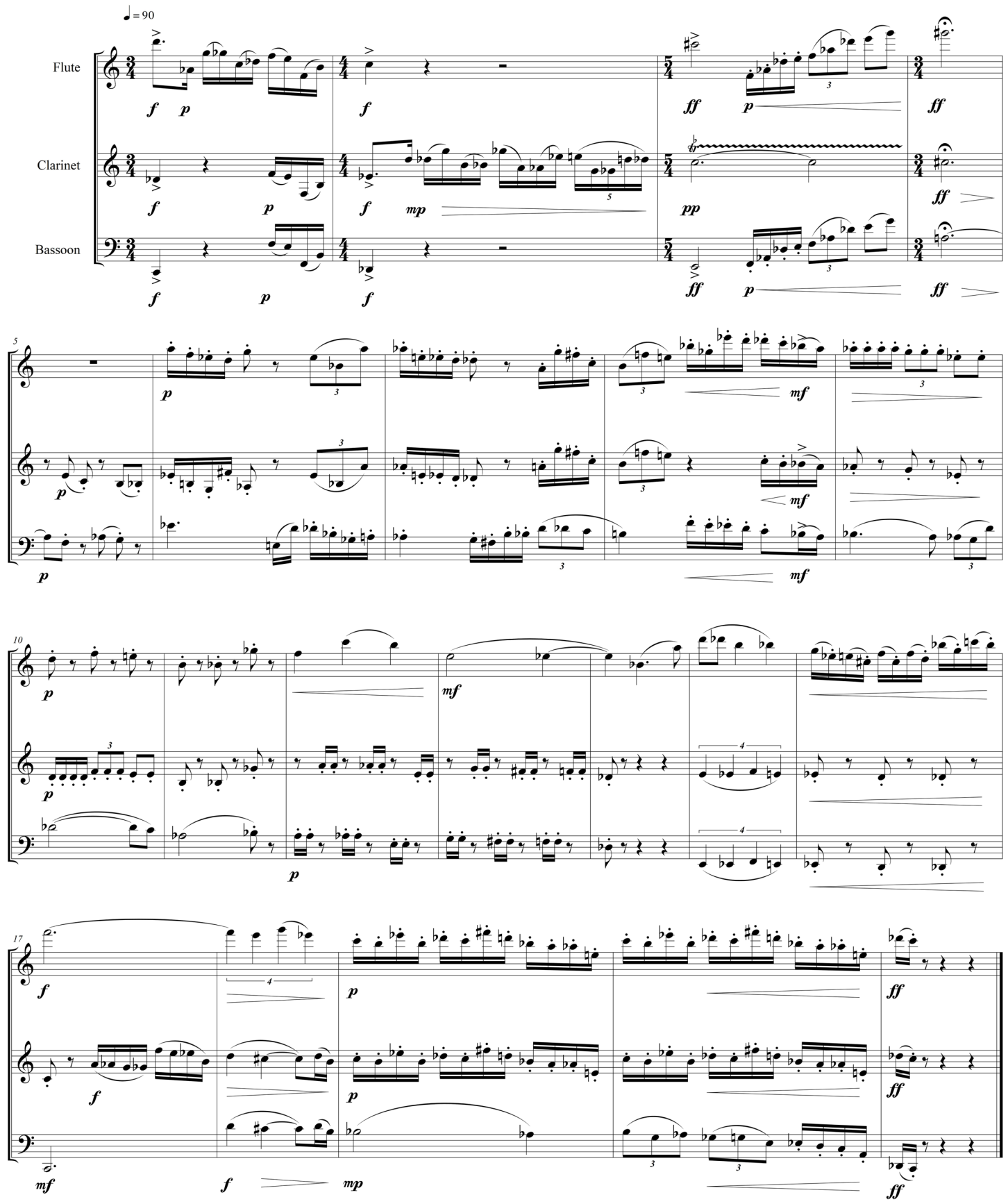

Example 8: The juxtaposition of the fragment composed with Ockam System and the fragment composed with Ponteio System

In this paper, we have taken as a starting point the concept of compositionality, proposed by Paulo Costa Lima as an interpenetration of five vectors: inseparability, creation of worlds, criticality, reciprocity, and processes of composing. From that we have described a hierarchy, in which compositional systems emanate from a certain universe, which is a world with its own laws that interact in a coherent way, ensuring cohesion and, therefore, its own existence. 
The universe mentioned here is not necessarily our natural universe, but it can be created from the establishment of laws, even in contradiction with respect to our natural system. This universe is revealed compositionally by the alternation between theory and practice, two inseparable principles in the process of composing. Such a manifestation is itself a creation of new worlds. Two experiments were conducted. In the first one, an original system (Ockam System) was defined and used to compose a small fragment from two basic laws inherited from our everyday universe (power conservation and parsimony). In the second experiment, an excerpt from Paulo Costa Lima's Ponteio Op. 35 was modeled, producing a system (Ponteio System) from which we have planned and composed another small fragment. As we have seen, even though this new fragment maintains the intervallic narrative of the original piece many immediate characteristics were lost in the modeling process: timbre, ostinato figurations, pitch, articulation, and dynamics. The performance of a system is, therefore, an activity that can establish a creative identity, a compositional voice, even when it takes its laws of organization from an original work.

\section{References}

1. Bertalanffy, Ludwig von. 2008. Teoria Geral dos Sistemas. Tradução: Francisco M. Guimarães. Petrópolis: Vozes.

2. Cerqueira, Fernando. 2007. Artimanhas do compor e do pensar: percurso criativo através dos textos. Salvador: Quarteto.

3. Cohn, Richard. 1998. Introduction to Neo-Riemannian Theory: a Survey and a Historical Perspective. Journal of Music Theory, V. 42 No.2: 167-180.

4. Cone, Edward T. 1982. Schubert's Promissory Note: An Exercise in Musical Hermeneutics. 19th-Century Music, V. 5, N. 3, p. 233-241.

5. Ferrero, Guillaume. 1894. L'inertie mentale et la loi du moindre effort. Revue Philosophique de la France et de l'Étranger V. 37, p.169-182.

6. Johnson, Peter. 1997. Musical Works, Musical Performances. The Musical Times, V.138, N.1854, p.4-11.

7. Larson, Steve. 2012. Musical forces: motion, metaphor, and meaning in music. Bloomington, IN: Indiana University Press.

8. Lima, Paulo Costa. 2012. Teoria e Prática do Compor I: Diálogos de invenção e ensino. Salvador: EDUFBA. 
MUSICA THEORICA Revista da Associação Brasileira de Teoria e Análise Musical 2019, v. 4, n. 2, p. 113-133 - Journal of the Brazilian Society for Music Theory and Analysis @ TeMA 2019 - ISSN 2525-5541

9. Pelletier, Francis J. 1994. The Principle of Semantic Compositionality. Topoi, v.13, p.11-24.

10. Pitombeira, Liduino. 2012. Diálogos entre a Musicologia e a Composição à luz de três modelos composicionais. In: VOLPE, Maria Alice. (Org.). Teoria, Crítica e Música na Atualidade. Rio de Janeiro: Universidade Federal do Rio de Janeiro, Escola de Música, Programa de Pós-graduação em Música, v. 2, p. 261-272.

11. Souza, Rodolfo Coelho de. 2007. Sintaxe e parataxe na música moderna e pósmoderna. Opus, Goiânia, v. 13, n. 2, p. 73-91.

12. Smith, Stuart; SMITH, Sylvia. 1979. A Portrait of Herbert Brun. Perspectives of New Music. v. 17. n. 2, p. 56-75.

13. Xenakis, Iannis. Formalized Music. 1990. Hillsdale, New York: Pendragon. 